\title{
Ethnologies
}

Street Dreams \& Hip Hop Barbershops: Global Fantasy in

Urban Tanzania. By Brad Weiss. (Bloomington, IN., 2009, Indiana University Press. Pp. 280. ISBN : 978-0-253-22075-2.)

\section{Jennifer Bentley}

Volume 33, numéro 1, 2011

URI : https://id.erudit.org/iderudit/1007809ar

DOI : https://doi.org/10.7202/1007809ar

Aller au sommaire du numéro

Éditeur(s)

Association Canadienne d'Ethnologie et de Folklore

ISSN

1481-5974 (imprimé)

1708-0401 (numérique)

Découvrir la revue

Citer ce compte rendu

Bentley, J. (2011). Compte rendu de [Street Dreams \& Hip Hop Barbershops: Global Fantasy in Urban Tanzania. By Brad Weiss. (Bloomington, IN., 2009, Indiana University Press. Pp. 280. ISBN : 978-0-253-22075-2.)]. Ethnologies, 33(1), 307-309. https://doi.org/10.7202/1007809ar d'utilisation que vous pouvez consulter en ligne.

https://apropos.erudit.org/fr/usagers/politique-dutilisation/ 
Street Dreams \& Hip Hop Barbershops: Global Fantasy in Urban Tanzania. By Brad Weiss. (Bloomington, IN., 2009, Indiana University Press. Pp. 280. ISBN : 978-0-253-22075-2.)

In the past decade, the east African nation of Tanzania has undergone a significant amount of change, especially in business. A notable shift away from state-run businesses - and the poverty resulting from a lack of jobs - resulted in a boom in entrepreneurialism. In this work, Brad Weiss delves into one burgeoning area of self-made business, that of the streetside barbershop (kinyozi), which proliferates in the northern Tanzanian city of Arusha. Weiss finds that these shops are emblazoned with Western motifs, particularly those of the American hip hop scene. Weiss discusses how a neoliberal revolution - that is, this move to entrepreneurial business - in Tanzania has brought popular culture from the West to the forefront in Arusha. As a result, those who spend their time socializing in new public places - such as the kinyozi - consider everything from the so-called "invincibility" of hip hop musicians to the stylings of televised soap operas to be learning experiences: lessons in self-fashioning for the modern African urbanite.

Hair, in Tanzania, causes a great deal of tension. Weiss explains that while one must maintain a modern sensibility ("keep up with the times"), one cannot spend too much time on appearance, for fear of being labelled as someone who is too busy with appearance to really be "surviving" in the same manner as other men in Arusha. Furthermore, longer hair or entirely bald heads can even lead to trouble with the police. Oddly, these are the very styles that are exhibited on the posters and in the iconography emblazoned on the walls of the kinyozi, which beautifully illustrates Weiss' point that Arushan men are not imitating or appropriating the styles of hip hop; rather, they are identifying with the capacity of its figureheads to survive rough situations.

In his fourth chapter, entitled "The Barber in Pain," Weiss offers a particularly detailed view of the kinyozi as a social space, and how it functions as a space for the men in Arusha, enabling them to deal with their mawazo ("thoughts" or worries), thus temporarily easing the pain they experience while surviving street life. Because of this function, Weiss argues that the act of cutting hair could be seen as a way of gaining control over an urban lifestyle. This chapter clarifies many of the concepts - especially the ever-present problem of the global interacting with the local - presented at the outset of the book, and 
seems to get to the heart of the social meaning of the barbershop. The reader might be better served by being provided with this information earlier. However, the discussion is nevertheless very welcome at this point in the book, and Weiss unpacks his complex theories in a way that gracefully makes the chapter readable and full of detail.

Weiss is not only concerned with the ins and outs of the kinyozi; he also provides portraits of individual entrepreneurs (working in fields as diverse as tailoring, signmaking, and cooking), as well as the culture and issues of representation found in particular entrepreneurial activities. His look at the daladala (minivan) transport system is particularly insightful, as ideas of invincibility and survival, represented by the tough images of African American hip hop artists and their surroundings, permeate both the daladala world and that of the barbershops. These narratives provide a much more thorough look at the condition of life in Arusha overall, and illustrate how recurring motifs of pain and survival - and their resulting connection to the American hip hop scene - inform everyday life in this city. These portraits are refreshingly well written, and allow the reader to step out of the kinyozi in order to place them in their larger urban setting.

Weiss does tend to repeat aspects of history that are not quite appropriate in the context of his subject matter; for example, he never satisfactorily explains how the rift between Pentecostal and Lutheran Christians, which he mentions several times, affects the lives of his mostly Muslim informants. He does, however, provide an in-depth discussion of how the general religious revival in Tanzania is manifested in music and the discourses of pain and suffering in everyday life, a discussion that answers questions about how devotion to Islam and general "thuggery" can easily go hand in hand.

Perhaps the most insightful part of the book involves Weiss' discussion of gender oppression; any reader might find him or herself wishing for more on the gendered aspects of barbershop life. Weiss could easily put together another manuscript on the divide between female beauty salons and male barbershops, which not only cater exclusively to the clientele of these respective genders, but also echo the values and livelihoods of the people they serve. The male rejection of female power, for example, unfolds quite brilliantly in Weiss' narrative. To these men, their male friends are much more important to their "survival" than any female companions, even those with whom they have fathered 
children or to whom they have other family ties. I believe he could add to his discussion by connecting this rejection of the feminine in favour of male companionship to an existing military mentality, given that he mentions earlier in his book that these men also have a great deal of respect for the army. Furthermore, possible self-consciousness in the face of real feminine power could lead to this favouring of male companionship, and though he approaches this idea by stating that matrilineal family units proliferate in Arusha, he skirts around the notion that the rejection of this power could be due to self-consciousness.

The kinyozi in Arusha provide an unexpected venue for inspiration, education, and self-fashioning for the men who socialize in them. A corner of Africa, so much part of everyday life, dips into commercialized Western culture for inspiration in a world where survival is the ultimate goal. Weiss tiptoes around some of the relevant issues in his account, but otherwise he provides a colourful, detailed picture of how fantasy and imagined realities play out in the medium of the urban Tanzanian barbershop.

Jennifer Bentley

Memorial University of Newfoundland

Listen to the Land: Conservation Conversations. By Dennis Boyer. (Madison, Wl., 2009, Terrace Books. Pp. 216. ISBN 978-0-299-22564-3.)

Whether you are a soldier who was once left behind in the unforgiving climate of 1970s Cambodia, a freight conductor from La Crosse, or a boatwoman living the emancipated life of a river-rat in Red Wing, Minnesota, you have a story to tell about your understanding of the earth around you. The late "Chubby Chippewa of Red Cliff" (3) once told Dennis Boyer that a story could entertain, educate, counsel, or heal. And from time to time a story can do all of these things and bring about a transformation of the opinions along with a change in the behaviour of its listeners. In Listen to the Land, Boyer brings together as diverse a range of stories as the American Midwest has to offer. Many of these stories contain a certain energy that, if heard by the right person, could indeed be transformative. 